\title{
Sustainability, Accreditations, Ecotourism and SDGs - the GSTC way, in India
}

\author{
Freeda Maria Swarna M' ${ }^{1,}$ Shaheed Khan ${ }^{2}$, R. Kannan ${ }^{3}$, S. Praveen Kumar \\ Research Scholar, Centre for Tourism and Hotel Management, Madurai Kamaraj University, Madurai, India ${ }^{1}$ \\ Research Scholar, Centre for Tourism and Hotel Management, Madurai Kamaraj University, Madurai, India ${ }^{2}$ \\ Professor and Director, Centre for Tourism and Hotel Management, Madurai Kamaraj University, Madurai, India ${ }^{3}$ \\ Assistant Professor, Centre for Tourism and Hotel Management, Madurai Kamaraj University, Madurai, India ${ }^{4}$
}

\begin{abstract}
Ecotourism, a niche tourism sector globally is preferred by the visitors to travel to destinations that provide for nature-based tourism (NBT) products. Around Ecotourism, the nuances of Sustainability, Responsible Tourism, Community Based Ecotourism (CBE) have made a mark. Climate Change, disasters, bring in an element of how to manage fragile destinations that come under the umbrella of Ecotourism. The facet of quality has been in currency when it comes to hospitality and transport; Ecotourism has joined the bandwagon. How to consider a Ecotourism destination sustainable, ensuring zero impacts on the environment, helping to preserve and conserve the ecology, how to support the local community have become important measures in the world of tourism today. Thence, the finer aspects of assessments, accreditations, certifications, will become standards that will enable Ecotourism destinations and standalone resorts and properties to invite the visitor to experience nature. Though few in number assessing, accreditating and certifying agencies the world over, are making the best of efforts to assuage the finest of sustainable elements, but also provide important marketing tools for the end users. It is pertinent, that opportunities are provided both to the user and the visitor to get the best of the Ecotourism site. The research study undertaken is a work in progress, which will enable the reader, academia and practitioner to understand at what stage we are in India in regards to assessments, accreditations and certification. The role played by the Government machinery which owns the base product of Ecotourism, the forests and the private and Global players. The Ecotourism canvas of India is still foraying into the assessment, accreditation and certification domain and a world leader like Global Sustainable Tourism Council (GSTC) has important role to play. The concentration of the current agencies who are focussing only on the environmental aspect; whilst the GSTC certification mechanisms is focussing on Social-economic, cultural and Environmental.
\end{abstract}

Keywords: Ecotourism, Accreditation, Assessment, Certification, SDGs

\section{INTRODUCTION}

The purpose is to achieve the benefits of sustainable tourism in a destination based on the careful analysis of the unique circumstances in the destination and engagement with key stakeholders (Day, Jonathon et.al., 2020).

This paper will try and analyse the Ecotourism Niche and the extent to which sustainability measures are in place, authentically and holistically. The research paper articulates the facet of Ecotourism in India and how the business of Ecotourism should be modulated to ensure Sustainable Tourism (ST), Responsible Tourism (RT) and Community Based Ecotourism (CBE).

Talking of sustainability in this space, the key stakeholders would be the Forest Department, the Communities who live around the destinations where sustainable tourism is being practiced (our lookout and work have been destinations near the forest areas), civil society, skill development institutions, local institutions (legal and traditional) and, the most important stakeholders, the visitors. Wherein all the stakeholders, the community, the forest departments at the provincial/state level are in control of the forests to conserve and preserve, the travel trade, the transporters, the nature guides, the destination management organization (DMO) and local businesses, who contribute to the qualitative growth of Ecotourism. All the aspects get encompassed in the nomenclature of getting a destination or an Ecotourism oriented resort accredited and/or classified for aspects that will provide for the approval of the quality of practice that has been adopted over some time and as per standards the world contemplates from time to time as important and unique for sustainable practices. 


\title{
International Advanced Research Journal in Science, Engineering and Technology
}

\author{
Vol. 8, Issue 8, August 2021
}

\section{DOI: 10.17148/IARJSET.2021.8891}

Sustainability, Sustainable Tourism, Sustainability Accreditations, juxtaposing the Ecotourism product and other tourism products with Sustainable Development Goals (SDG) has become an important narrative considering the fact the deadline is 2030 (UN SDG). How can each of the stakeholders contribute towards the SDG goal? A goal that will help the survival of the human elk; along with the stakeholders of the environment we live in.

\section{ECOTOURISM}

The UNWTO definition for Ecotourism "ecotourism" refers to forms of tourism that have the following characteristics:

1) All nature-based forms of tourism in which the main motivation of the tourists is the observation and appreciation of nature as well as the traditional cultures prevailing in natural areas;

2) It contains educational and interpretation features;

3) It is generally, but not exclusively organised by specialised tour operators for small groups. Service provider partners at the destinations tend to be small, locally owned businesses;

4) It minimises negative impacts upon the natural and socio-cultural environment;

5) It supports the maintenance of natural areas which are used as ecotourism attractions. (GSTC, 2021) Such tourism is in keeping with the aspirations of local communities for tourism, has low negative tourism impacts on the community, is educational for the tourists and conserves the environment. (GSTC India Team, 2021).

Established in 1990 (TIES, 2019), The International Ecotourism Society (TIES), has been at the forefront of Ecotourism development, providing guidelines and standards, technical assistance, capacity building through training and educational resources. The 1990 definition of Ecotourism by TIES was, "responsible travel to natural areas that conserves the environment and improves the well-being of local people." (Bricker, Kelly, 2017). By 2015, TIES defined Ecotourism as, "responsible travel to natural areas that conserves the environment, sustains the well-being of the local people, and involves interpretation and education." (Conserve Energy, 2021). From these definitions, it is clear that the main facet was to ensure conservation and preservation qualitatively.

For the general reader and research this paper will help one to understand the pertinent aspects of Ecotourism leading towards quality measures of accreditation, assessment, and certification; for which the writing of Patterson (2001) and the classification of Ecotourism helped us to reach the nuanced approach to understand the issue further. (NOTE: For a qualitative understanding of how we targeted what Carol Patterson had evolved, we have placed our view and interpretation in-line to each point that is worth considering for any Ecotourism practitioner or general administrator who would bring in interventions to help assuage the issue/issues being faced and bring about a good scenario for Sustainable Ecotourism practices leading to CBE.)

1. Have a low impact upon a protected area's (PA) natural resources and recreation techniques. (This is where the nuances of Sustainable Tourism arise, and considering that the Community knows the PA well, they will be able to work in tandem with the FD and ensure for all the stakeholders and provide for an experience for the visitors.)

2. Involve stakeholders (individuals, communities, ecotourists, tour operators and government institutions) in the planning, development, implementation and monitoring phases. (The primary stakeholders are the Community and the FD officers who will be the mainstay as part of the Government. In India, the Local Self Government (LSG) lead by the Gram Panchayat helps in establishing a structure and a backing to the functioning which is mandated by the Constitution of India) [The last level of Government Administration, but the cutting edge, as people will be able to decide as to what is needed by the Community. The Government of India, through various interventions and off course backed by the Constitution $73^{\text {rd }}$ Amendment has focused on the Panchayati Raj Institutions (PRI) which will add value to the functioning of these SPVs. The creation of the Gram Panchayat Development Plan (GPDP) adds a fillip to the functioning of the Ecotourism destination and brings in cohesion.]

3. Limits visitation to areas, either by limiting group size and/or by the number of groups taken to an area in a season. (Sustainability ushers in the facet of "carrying capacity" of the visitors that the destination can take; this ensures that the destination will ensure 'zero' over-crowding and the aspect of "over-tourism" (Ali, 2018) that has been seen an impact and a pass-over of "mass tourism)

4. Supports the work of conservation groups preserving the natural area on which the experience is based. (The Community is the best bet to preserve and conserve the PA under the watchful eyes of the FD and other NGOs who would like to contribute through the means of training/skilling and support aspects)

5. Orients customers on the region to be visited. (Visitors of today, are mature and would engage in sustainable tourism products. More visitors of today, are making an effort to reach out to destinations that focus on Sustainability and with a focus on carrying capacity)

6. Hires local people and buys supplies locally, where possible. (The Ecotourism SPV provides for the finest of opportunities of livelihood options for one and all in the area. It can range from Naturalists to managing restaurants, to managing resorts, adventure activities; it gives for ample amount of Income Generating Opportunities) 


\title{
International Advanced Research Journal in Science, Engineering and Technology
}

\author{
Vol. 8, Issue 8, August 2021
}

\section{DOI: 10.17148/IARJSET.2021.8891}

7. Recognizes that nature is a central element to the tourist experience. (Visitors of the day are preferring to make headway to destinations that are in the genre of Nature-Based Tourism (NBT) and this is sure adding value to Ecotourism)

8. Uses guides trained in the interpretation of scientific or natural history. (Naturalists who are locals are the best bet in any NBT destination, as they know the environs well)

9. Ensures that wildlife is not harassed. (This is the primary prerogative of the FD and the SPV supports the action.)

10. Respects the privacy and culture of local people. (Since the locals are involved, they are aware of what is to be provided and what need not be done. The Do's and Don'ts are well prescribed)

\section{A: QUALITY, ACCREDITATION, ASSESSMENT, CERTIFICATION: EVOLUTION}

According to a recent Booking.com (2020) survey conducted with more than 29,000 travellers spanning 30 countries, $56 \%$ of the visitors agreed to the fact that they will seek out more rural, off the beaten-track experiences to immerse themselves into the outdoors. $83 \%$ said sustainability is important, while $61 \%$ reported that the pandemic has inspired them to travel more sustainably. In $2021,81 \%$ of travellers surveyed said they intended to stay in a "sustainable accommodation" at least once in the coming year, compared with $74 \%$ in 2020 and only $62 \%$ in 2016 . And $76 \%$ said they would seek out places to stay with a third-party sustainability certification from a reputable source. There is a gap in understanding clear standards when it comes to defining sustainability that can leave travellers confused, how these standards are regulated? and their overall impact on the environment.

No doubt the aspect of quality in the Environmental eco-system has been dabbled the world over through various facets and systems, viz., the Environmental Management Systems (EMS) and the components that it brings about. True when we speak about EMS in the corporate what stands out are the ISO 14000 and 14001 EMS standards which have a uniformity across the world that bring value to the businesses.

The advantages (ASQ, 2021) of EMS standards have been:

1. Ensuring a holistic approach to environmental impacts

2. Focusing on only critical aspects and processes

3. Making use of time-tested, mature approaches recognized worldwide

4. Establishing positive relationships with regulators

With Ecotourism all over India and new ones coming into the tourism scenario, is there is a need for 'ecolabel' that will put a meaning to the destination located in the fragile area viz., the forest, where most of the Ecotourism in India happens? India boasts of a robust Hotel Labelling system that is coordinated and managed by the Government of India, Ministry of Tourism and the states in India. The Hotel Classification system has been uniquely run without any ubiquities and has contributed a lot to the evolution of the Accommodation system. Font (2007), suggests, there has been near consensus on the Ecotourism certification, that is the showcasing of good and best practices, and more attempts to measure eco and sustainable behaviour, set standards, certify those meeting the standards, and provide for market benefits to such stakeholders. Certification was thereby defined as a "voluntary process that assesses, monitors, and gives written assurance that a business, product, process, or service conforms," to a set of standards and in most cases, compliance of the norms is rewarded with a selective logo (Honey, Martha, 2002).

At the most, basic level ecotourism certification programs are meant to help translate the fundamental principles of ecotourism into operation and in doing so create transparency in the industry and generate market demand (McLaughlin, Juliene Melissa, 2011). For this to happen, ecotourism certification programs need to develop common global standards to promote authentic ecotourism products in hopes that the label will support these ventures that meet specific and regulated standards (Font, X, 2007). The need for standardization was recognized at the World Ecotourism Summit in 2002 which spoke of the broader concept of "sustainable tourism" as often a more effective policy position, though ecotourism plays an important role in further setting the standards for the protection of the natural and cultural environment (World Ecotourism Summit, 2002). The resultant document, The Quebec Declaration on Ecotourism (attended by 1200 delegates from 133 countries) (UNEP, 2002), proposed a set of recommendations to national, regional and local governments that included the use of "internationally approved and reviewed guidelines to develop certification schemes, ecolabels and other voluntary initiatives geared towards sustainability in ecotourism.... that should reflect regional and local criteria." The report also spoke to too many labels that would lead to much confusion. They suggested a possible solution of VISIT, a joint-European initiative for the promotion of ecolabels and sustainable tourism development. By bringing in cooperation of ten ecolabels of Europe, common basic standards for their criteria and verification procedures were evolved, which guaranteed high environmental quality of their certified hotels, campsites, 


\title{
International Advanced Research Journal in Science, Engineering and Technology
}

\author{
Vol. 8, Issue 8, August 2021
}

\section{DOI: $10.17148 /$ IARJSET.2021.8891}

beaches or marinas. By 2004 VISIT became the European accreditation body for ecolabels in tourism. One fall out of the Quebec Conference was to ensure to have certification schemes that will work at the local level and at the same point in time have international recognition was surely a precursor to the current systems of accreditation and certification. One can get a bird's eye view of the main recommendations for Certification of the Ecotourism/Tourism products through the following:

i) Provide guidelines on certification schemes for ecotourism. *

ii) Avoid penalising very small-scale enterprises and facilitate their access to certification schemes. .

iii) Involve all stakeholders in developing and implementing certification processes. ·

iv) Ensure certification processes are transparent, understandable and updated.

v) Ensure monitoring

vi) Establish continuous data collection

The statement for the future was, "certification process needs to be global in concept, following international guidelines and recommendations, but local in application." And the most important facet that was advised to all the stakeholders was: Certification should take into account Social, Economic and Cultural aspects besides, the Environmental ones.

Global Sustainable Tourism Council (GSTC), another very important stakeholder in Sustainable Tourism operations too has pitched in to ensure the nuances of certification are well captured. As mentioned by Durband, Randy (2020), the UN agencies UNEP and UNWTO joined forces in 2005 to create definitions and pathways for sustainable tourism, which included the founding of GSTC, in 2007 with the collaboration of leading international conservation organizations and important players in the Tourism sector. Their primary purpose in creating GSTC was to develop and manage global standards for sustainable tourism. The GSTC Industry Criteria were launched in 2008, followed later in 2013 with the GSTC Destination Criteria, collectively addressing the needs of the private sector and the public sector. It can therefore be seen that efforts at an international level are what lead to the articulation of the thought process to ensure standardization and a process of accreditation and certification, which will usher in the necessary change for the Sustainable Tourism paradigm. Pacific Asia Travel Association (PATA) (estb. 1951) (PATA, 2021) a not-for-profit membership-based association functions as a catalyst for the Responsible Development of Travel and Tourism, within the Asia Pacific region clearly confirms through Mr. Mario Hardy, CEO,”....certifications on one hand raise awareness, and on the other pushes people to constantly improve.......there are many certification schemes competing against each other......Asia is different from Europe, so as any other business, certifying boides have to adopt their market strategies...." (Galewska, Anula, 2017). Clearly one needs to understand the importance of the Certification, the actual mechanism and the modalities adhered to.

Some other trust worthy certification agencies across the world are Denmark-based Green Key for ustainabiltity in the hospitality industry, the U.S. Green Building Council's Leadership in Energy and Environmental Design (LEED), holds a host of other certifications, including Green Globe Platinum, ISO 14001 for environmental management, ISO 9001 for quality standards, and Travelife Gold. Green Globe, which requires hotels' purchasing policies to favor environmentally friendly products .

Fig. (1) provides a very understanding that the various facets of customer satisfaction viz., Sustainability, Quality and Health, Hygiene, Safety are all interrelated. No doubt the framework of the three-legged stool became pertinent, and if any of the legs fail, then the stool (Customer Satisfaction) collapses. There was much juxtapositioning of the thought process in regards to accreditation and assessment at the beginning of the twenty-first century. World over the Certification schemes has been widely used in the corporate world to promote the implementation of standards, to reward those who achieve specified objectives, and to enable customers to identify operations that comply with applicable standards. The Hotels, Hospitality and Restaurants businesses have adopted quality certifications and standards (Honey, Martha, 2002).

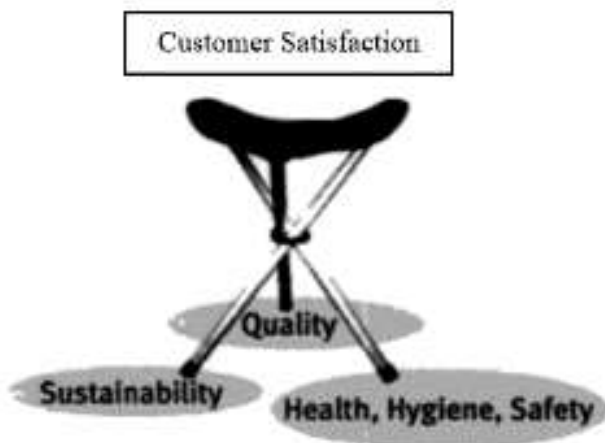

Fig. 1: The Tourism Industry's three-legged stool for customer satisfaction (Honey, Martha, 2002) 


\title{
International Advanced Research Journal in Science, Engineering and Technology
}

\author{
Vol. 8, Issue 8, August 2021
}

\section{DOI: $10.17148 /$ IARJSET.2021.8891}

The earliest of tourism standards no doubt focused on the three-legged stool which stood for the following:

Quality: the needs and expectations of the tourists are principally through personal interactions and service providers. The overall vacation experience of the guests is effectively managed by the staff in the units of maintenance, housekeeping, food and beverages (production and service), and others who process the general facilities and furnishings.

Sustainability: Here the focus is on adverse impacts of tourism to ensure the future of the destination by reducing and preventing the negative impacts. The tourists/visitors are also interested these days and interested to know the socioeconomic and cultural issues and the impacts leading to the protection and conservation of the environment, the nature that they have been a part of.

Health, hygiene and safety conditions: Safety and security have become primordial to the tourist of today (and even tomorrow); safety and the factors of hygiene and health are taken very seriously and without any caveats. "We need them," as a visitor to an Ecotourism destination managed by the local community in the Southern part of India, put it.

Thence, the three-legged stool becomes even more pertinent to this day and age. The outlook thereby would be to have a certification process and procedure which will assimilate and cater to the needs and requirements of the visitors/tourists, who are the end consumers, the environment; which does not speak for itself, but shows up through disasters, which ultimately is manmade and off course, the usher in the world order and protect and prevent the human elk from extinction and also the environment and ecology, the flora and fauna, the International bodies like the United Nations, United Nations Environment Program and others, who put forward the well-accepted, and attempts to practice by Governments, the people, the businesses; the Sustainable Development Goals (SDG), which we are a global population are to achieve by 2030 or face the wrath of Nature.

It can therefore be seen that Ecotourism and Sustainable Tourism should move from "Good Concepts" to "good practices," and surely, they need to be measured against clearly set standards (Honey, Martha, et.al. 2007), that will help in the providing of a metric; which will further the cause of Ecolabeling, 'green' tourism certification and Ecotourism Certification. It has been accepted fact that the certification programs are more on the 'voluntary' kind as these certifications ensure participation from the stakeholders, for it not only for their good but the good of the community, the visitors and even the stakeholders, who may be directly or indirectly visible to the tourism product/destination.

Considering the number of countries and the Ecotourism destinations that can get to count, it would be a humongous task to ensure a certificate at the global level and promote 'green' tourism certification. With close to two hundred countries that dot the globe, it is clear that; there is a lot of unevenness in the certification programs. The big question is, 'is there a set global criterion', that every destination or resort can follow? Is there a global accreditation body that will provide for the needed top-down approach, which will surely simplify the matter and ensure local adaption of parameters for certification?

ISEAL (https://www.isealalliance.org) is the global membership organisation for ambitious, collaborative and transparent sustainability systems. From setting standards and codes to criteria reviews. They work at the National, sub-national and regional levels. With so many sustainability systems out there, how can businesses know which tools are best placed to help meet their objectives, whether that's developing deforestation-free supply chains, ensuring workers' rights, promoting gender equality, supporting regenerative agriculture or managing climate and water risks? (Peeling, 2021). ISEAL's Credibility Principles address these questions by defining the foundations of good practice for sustainability systems. One should assuage the facts and make efforts to have good quality management systems in the domain of Ecotourism, and organizations like ISEAL stand out.

Rainforest Alliance (2002) explains, "assess and help standardize" sustainable tourism certification programs and to help with "functions such as marketing, training and development," which has brought about an understanding for the current business enterprises and will have a bearing on the future as well. The researchers made an effort to identify if any individual or organization has defined Ecotourism accreditation and certification and who would or should be considered as one of the first to make a statement on the same. There are more than 50 ecotourism certifications at last count including Australia's ECO Certification, Costa Rica's Certificate for Sustainable Tourism, Fair Trade Tourism Alliance, Ecotourism Kenya, Seychelles Sustainable Tourism Label, and Rainforest Alliance. Eco-Tourism Australia (2021), in a way, pioneered the certification facet, which is very well articulated as the following:

The ECO Certification program certifies tourism products (tours, accommodation, attractions) with a primary focus on nature. It assures travellers that certified products are backed by a strong, well-managed commitment to sustainable practices and provides high-quality nature-based tourism experiences. The ECO Certification program is a world first and it has been developed to address the need to identify genuine nature and ecotourism operators. ECO Certification 


\section{International Advanced Research Journal in Science, Engineering and Technology}

Vol. 8, Issue 8, August 2021

DOI: 10.17148/IARJSET.2021.8891

is product-specific - this means that you will need to answer the criteria as it applies specifically to each of your products. This also means that you can apply for ECO Certification even if not all of your products are nature-based. ECO Tourism Australia even created various categories of Certification:
i) $\quad$ ECO Certified Tourism (for accommodations, tours and attractions);
ii) Climate Action Certification (for all sectors of the tourism industry);
iii) Respecting our Culture Certified (ROC) (for accommodations, tours and attractions: for products with a focus on visiting cultural areas or receiving cultural interpretation);
iv) ECO Certified Destination (for destinations with a focus on nature);
v) ECOGuide Australia Certified Guide (for Individuals and Guides of nature-based tourism experiences)

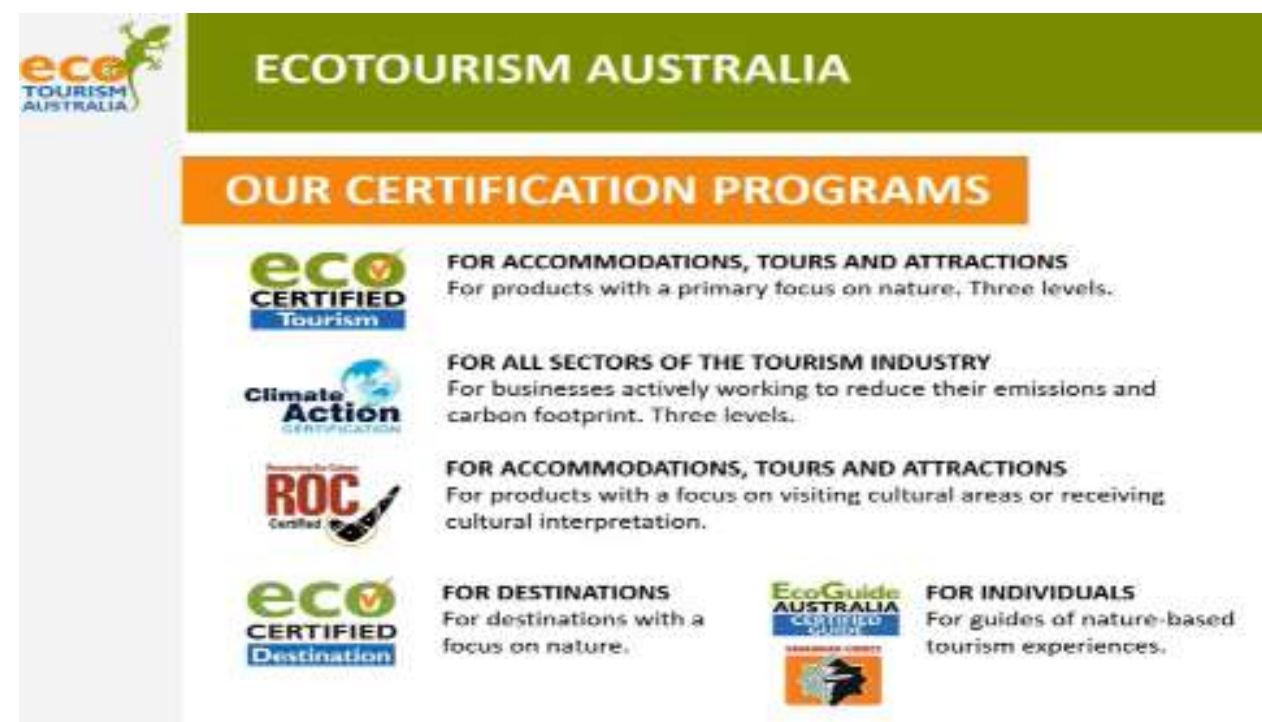

Table 1: Grab from Ecotourism Australia, YouTube video (Ecotourism Australia, 2021)

It was in 1996 (Ecotourism Australia, 2021) that ECO Tourism Australia has established for stakeholders to adopt and ensure the betterment of the Ecotourism business. As of 2021, 500 certified operators are focusing on more than 1700 tourism products.

The Eco Certification criteria adopted by Ecotourism Australia are as follows, which will help us to understand in a better way the need for criteria of accreditation, assessment and certification.

1. Business Management and Operational Planning

2. Responsible Marketing

3. Customer Satisfaction

4. Environmental Management

5. Interpretation and Education

6. Contribution to conservation

7. Working with local communities

8. Cultural respect and sensitivity

Accreditation, assessment and certification become pertinent on various accounts for it supports in the following manner:

a) Endures the businesses duty and responsibility to protect the environment (global and local),

b) Ushers in Accountability with the stakeholders and ensures protection and conservation. The sense of responsibility that comes about truly augurs well for the Ecotourism business and industry,

c) Help the industry and the business to recognize quality-oriented operators,

d) Provides for reassurance to the visitors about the destination or the practices that are being adopted,

e) Helps support the aspect of sustainability to one and all; leading to adoption the same by others. 

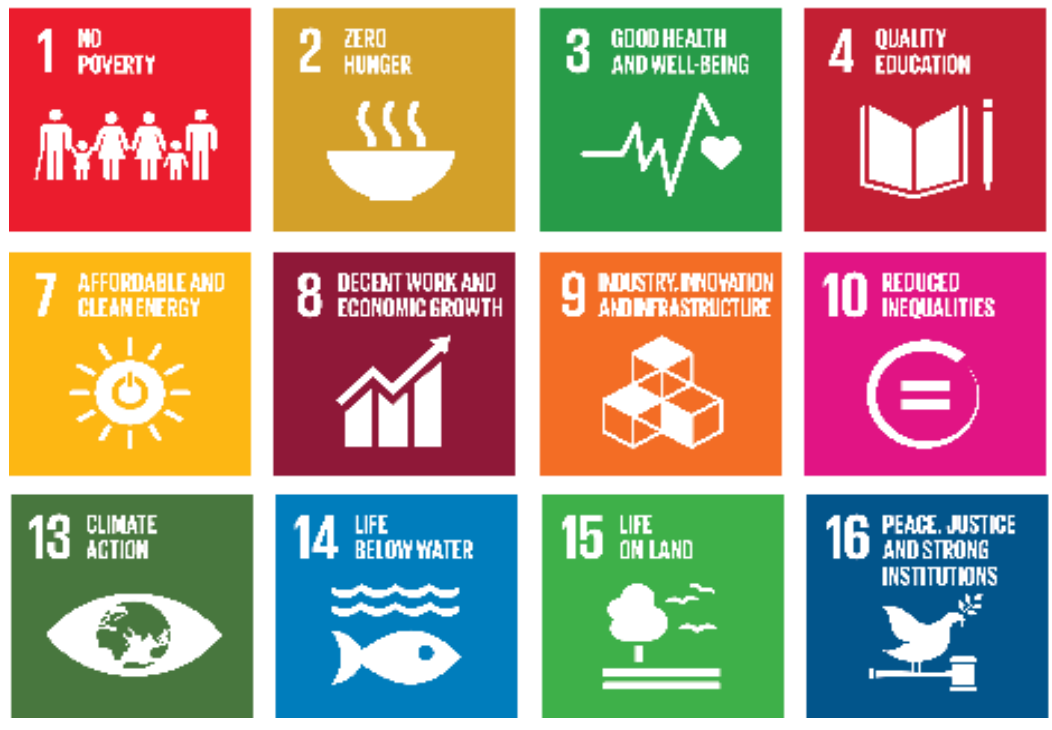
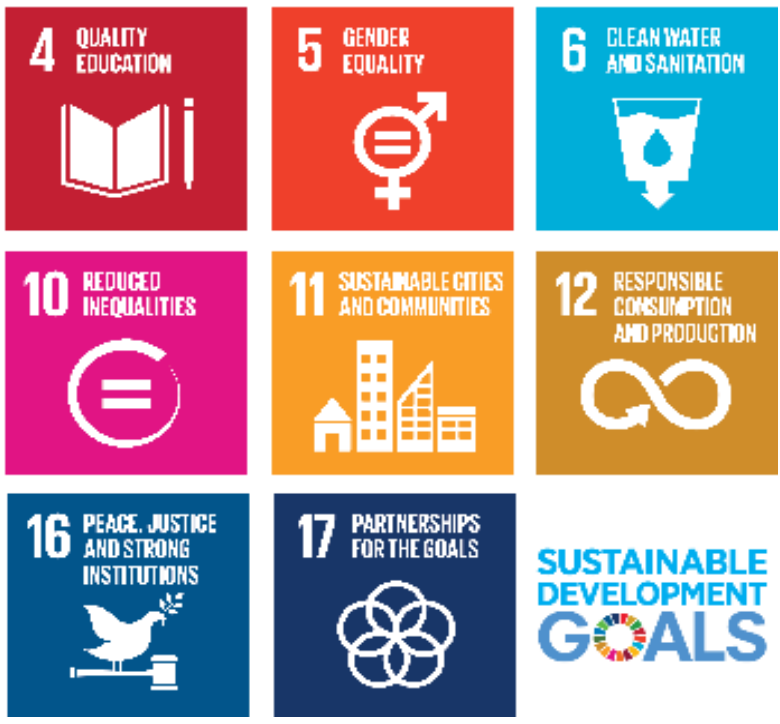

SUSTAINABLE DEVELOPMENT GALS

\begin{tabular}{|c|c|c|c|}
\hline Criterion & Sub-criterion & Deep-dive of criterion & $\begin{array}{l}\text { SDG } \\
\text { target }\end{array}$ \\
\hline \multirow{11}{*}{$\begin{array}{l}\text { SECTION A } \\
\text { Sustainable } \\
\text { Management }\end{array}$} & \multirow{3}{*}{$\begin{array}{l}\text { A (a) Management Structure } \\
\text { and Framework }\end{array}$} & 1. Destination Management Responsibility & 16 and 17 \\
\hline & & $\begin{array}{l}\text { 2. Destination Management strategy and } \\
\text { action Plan }\end{array}$ & 17 \\
\hline & & 3. Monitoring and reporting & 12 \\
\hline & \multirow[t]{4}{*}{ A(b) Stakeholder Engagement } & $\begin{array}{lll}\text { 4. Enterprise engagement and } & \text { and } \\
\text { sustainability standards } & \end{array}$ & 12 and 17 \\
\hline & & 5. $\quad$ Resident engagement and Feedback & 11 and 17 \\
\hline & & 6. Visitor engagement and feedback & 11 and 12 \\
\hline & & 7. Promotion and information & 11 and 12 \\
\hline & \multirow{4}{*}{$\begin{array}{l}\text { A(c) Managing Pressure and } \\
\text { Change }\end{array}$} & 8. Managing visitor volumes and activities & 11 and 12 \\
\hline & & $\begin{array}{l}\text { 9. Planning regulations and development } \\
\text { control }\end{array}$ & 9 and 11 \\
\hline & & 10. Climate change adaptation & 13 \\
\hline & & 11. Risk and crisis management & 11 and 16 \\
\hline \multirow{6}{*}{$\begin{array}{l}\text { SECTION B } \\
\text { Socio- } \\
\text { Economic } \\
\text { Sustainability }\end{array}$} & \multirow[t]{3}{*}{$\begin{array}{l}\text { B(a) Delivering local economic } \\
\text { benefits }\end{array}$} & $\begin{array}{l}\text { 12. Measuring the economic contribution of } \\
\text { tourism }\end{array}$ & 1,8 and 9 \\
\hline & & 13. Decent work and career opportunities & $\begin{array}{l}4,5,8 \text { and } \\
10\end{array}$ \\
\hline & & $\begin{array}{l}\text { 14. Supporting local entrepreneurs and fair } \\
\text { trade }\end{array}$ & 2,8 and 12 \\
\hline & \multirow[t]{3}{*}{$\begin{array}{l}\text { B(b) Social wellbeing and } \\
\text { impacts }\end{array}$} & 15. Support for community & 3 and 4 \\
\hline & & $\begin{array}{l}\text { 16. Preventing exploitation } \\
\text { discrimination }\end{array}$ & 10 and 16 \\
\hline & & 17. Property and user rights & 11 and 16 \\
\hline
\end{tabular}


DOI: $10.17148 /$ IARJSET.2021.8891

\begin{tabular}{|c|c|c|c|}
\hline & & 18. Safety and security & 3 and 16 \\
\hline & & 19. Access for all & 3 and 10 \\
\hline \multirow{7}{*}{$\begin{array}{l}\text { SECTION C } \\
\text { Cultural } \\
\text { Sustainability }\end{array}$} & \multirow[t]{5}{*}{ C(a) Protecting cultural heritage } & 20. Protection of cultural assets & 11 \\
\hline & & 21. Cultural Artefacts & 11 \\
\hline & & 22. Intangible heritage & 11 and 12 \\
\hline & & 23. Traditional Access & 11 \\
\hline & & 24. Intellectual Property & 16 \\
\hline & \multirow[t]{2}{*}{ C(b) Visiting Cultural Sites } & 25. Visitor Management at cultural sites & 11 and 12 \\
\hline & & 26. Site interpretations & 4 and 11 \\
\hline \multirow{12}{*}{$\begin{array}{l}\text { SECTION D } \\
\text { Environmental } \\
\text { Sustainability }\end{array}$} & \multirow{4}{*}{$\begin{array}{l}\text { D(a) Conservation of Natural } \\
\text { Heritage }\end{array}$} & 27. Protection of sensitive environment & 14 and 15 \\
\hline & & 28. Visitor Management at Natural sites & 14 and 15 \\
\hline & & 29. Wildlife interaction & 14 and 15 \\
\hline & & 30. Species exploitation and animal welfare & 14 and 15 \\
\hline & \multirow[t]{3}{*}{ D(b) Resource Management } & 31. Energy Conservation & 7 \\
\hline & & 32. Water Stewardship & 6 \\
\hline & & 33. Water quality & 3 and 6 \\
\hline & \multirow{5}{*}{$\begin{array}{l}\text { D(c) Management of waste and } \\
\text { emissions }\end{array}$} & 34. Wastewater & 3 and 14 \\
\hline & & 35. Solid waste & $\begin{array}{l}12,14 \text { and } \\
15\end{array}$ \\
\hline & & $\begin{array}{l}\text { 36. Greenhouse Gas Emissions and Climate } \\
\text { change mitigation }\end{array}$ & 13 \\
\hline & & 37. Low impact transportation & 9 and 13 \\
\hline & & 38. Light and noise pollution & 3 and 11 \\
\hline
\end{tabular}

There is a strong relationship between the GSTC Criteria and the SDGs. By adopting the GSTC Criteria, one is helping to meet the UN SDGs. Economic, environmental and societal dimensions all of which are addressed by the GSTC Criteria. Organizations and companies looking to contribute to the SDGs will find that the GSTC Criteria and other GSTC-Recognized Standards provide effective tools to help in rising to the challenge. SDGs are a call for action by all countries - poor, rich and middle-income - to promote prosperity while protecting the planet. They recognize that ending poverty must go hand-in-hand with strategies that build economic growth and address a range of social needs including education, health, social protection, and job opportunities while tackling climate change and environmental protection. CB Ram Kumar, Board Member and South Asia Director (Chair), GSTC, mentions there is a lack of awareness amongst the majority of companies about the true meaning of sustainability. It is usually equated to being green and environmentally sustainable. The SDG's have listed out a policy direction for overall Sustainability of which environment is also an important aspect - but not the only aspect. This lack of awareness is a result of no compulsion to understand sustainability completely. It is not a compliance issue that needs to be attended to. So, companies have not found the need to understand and get deep into aspects of sustainability (P Krishna Kumar, 2021).

\section{A: INDIA'S ECOTOURISM, ACCREDITATION, ASSESSMENT, CERTIFICATION, GSTC:}

India with its vast Ecotourism canvas would require a robust accreditation, assessment and certification mechanism, considering the Tourism in general and Ecotourism, in particular, is managed from the concept of preservation and conservation by the Forest Departments of the respective states/provinces. Besides with both the Federal (Government of India) and the States/provinces administering the forests, through the Constitutional mechanism, considering that Forests (Entry 17A) (Constitution of India, 2012a), Protection of wild animals and birds (Entry 17B) (Constitution of India, 2012b) comes under the Concurrent List of the Indian Constitution.

The Role Played by the Government of India: (Ministry of Forests Environment and Climate Change (MoEFCC) and Ministry of Tourism (MoT):

\section{B: NETWORK FOR CERTIFICATION AND CONSERVATION OF FORESTS (NCCF)}

Focusing on voluntary sustainability standard-setting organization, the Network for Certification and Conservation of Forests (NCCF), a not-for-profit organization, promoted to evolve and align forest certification programs within India was officially registered in January 2015. Besides, Ecotourism, NCCF is working towards developing national (NCCF, 2019) sustainability certification standards in diverse areas of natural resource management, majorly forestry, trees 


\title{
International Advanced Research Journal in Science, Engineering and Technology
}

\author{
Vol. 8, Issue 8, August 2021
}

\section{DOI: 10.17148/IARJSET.2021.8891}

outside forests, protected areas and wetlands, non-wood forest products, quality planting material, biofuels, sustainable mining, and water quality, etc. and also engaged in policy advocacy and diverse conservation activities.

The NCCF has got support from the key forest-based stakeholders such as the Ministry of Environment, Forest and Climate Change (MoEFCC) through its premier institutes like Indian Institute of Forest Management (IIFM), Indian Council for Forestry, Research and Education (ICFRE), and Indian Plywood Industries Research and Training Institutes (IPIRTI), Ministry of Agriculture and Farmers Welfare, Ministry of Commerce and Industry Export Promotions Council for Handicrafts (EPCH), ITC Ltd., Green Initiatives Certification and Inspection Agency (GICIA), Indian Paper Manufacturers Association (IPMA), Greenply, Dabur, Arya Vaidyasala, Kottakal, Paper, and Plywood Industries and many more in furtherance of its objectives. Considering that the focus has been on the Program for Endorsement of Forest Certification (PEFC) (found in 1999) and Forest Stewardship Council (FSC) (found in 1993); two global mainstream operational Forest Management Certification schemes, NCCF is on a good footing to ensure for the conservation and preservation of forests in India, and when it comes to Ecotourism, they can contribute to the best as Government, Private Sector, Academia and civil society is involved.

NCCF is of the firm belief that there is a growing realization among different forest/plantation-based stakeholders of the country that India needs to develop Forest Certification standards and systems, which governs the management of forest $\&$ forest produce on the principles of sustainable forest management (SFM) and ensures inspection, validation and verification of SFM parameters, and be eventually endorsed by a well-recognized international body in the field of forest certification. Here a role for GSTC can be seen to align the ideals of sustainable Ecotourism with the finer aspects of NCCF. Though for NCCF, Ecotourism will be one of the areas.

The firm belief of NCCF on Ecotourism, Standardization, Accreditation, Assessment and Certification is as follows: To enable sustainable growth of the ecotourism sector, the development of certification standards for ecotourism stakeholders is imperative. Certification leads to an independent third-party evaluation of ecotourism management practices market-driven mechanism, independent of legislative and policy fluctuations. The main objective of such standards is to promote responsible tourism, improved ecotourism management practices, improved wildlife resources, healthier forests and providing livelihood security to local people. Certification will also provide price premium and access to new ecotourism markets for such initiatives. Certification will also require proper management planning for each ecotourism area that will be prepared by professional landscape architects and urban planners in consultation with the local community (traditional knowledge) as well as others directly concerned.

The Role and responsibilities as envisaged by NCCF were as follows (NCCF, 2019):

i) A voluntary sustainability standard-setting organisation is involved with developing, coordinating, revising, amending, reissuing, interpreting, publishing and producing technical standards for assessment openly and transparently, of the efficacy and efficiency of functioning of a conservation entity, or its management practices

ii) This voluntary sustainability Standard for Ecotourism being developed is to follow an open, transparent and participatory approach involving multiple stakeholders

iii) The developed sustainability standard would be accredited by a competent organisation

iv) A certification body, in the current context, will be a third-party auditing entity that is competent to audit Ecotourism destinations against a specific standard or code. The minimum audit performance criteria will need to be fulfilled by each of the ecotourism destinations to obtain the mandated certification

At the state level, the states have created Ecotourism Development Boards (EDB), to place qualitative efforts on Ecotourism. Madhya Pradesh was the first to constitute a board, as an autonomous organization in the FD of the Government of Madhya Pradesh. The Board was constituted in July 2005 for the promotion and development of Ecotourism as a Mainstream program of the FD. The Board, apart from complimenting the FD with the necessary knowledge, skills and policy initiatives, would act as a centre of coordination between Madhya Pradesh Tourism, the FD and other stakeholders, for generating synergies between them. Within this larger mandate, the Board will focus on the achievement of certain objectives such as the development of infrastructure; development and enforcement of standards/norms of service; review and development of policies and laws; ensuring participation of a benefits of all stakeholders, especially the rural communities and capacity building support for stakeholders (MP Forest, 2016).

In some states, there are tourism development boards augmenting ecotourism. In some states like Uttrakhand, there are corporations. The Ecotourism Development Corporation (ETDC) of Uttarakhand, is formed under the Companies Act 2013. A letter was issued on 10 June 2016 by the state government for the formation of ETDC. According to the letter, the stated reason for the creation of ETDC was to encourage the promotion of ecotourism in Uttarakhand which has a rich biodiversity, wildlife and scenic beauty. Further, according to the same document ecotourism is essential to stop outmigration and strengthen the regional economy (Pande and Sharma, 2018). 


\title{
International Advanced Research Journal in Science, Engineering and Technology
}

\author{
Vol. 8, Issue 8, August 2021
}

\section{DOI: $10.17148 /$ IARJSET.2021.8891}

\section{C: SUSTAINABLE TOURISM CRITERIA AND INDICATOR (STCI) STANDARD AND ECOTOURISM} SOCIETY OF INDIA (GKToday, 2014)

In a proposal to augment its sustainability offerings, the Ministry of Tourism (MoT), Government of India (GoI) launched the comprehensive Sustainable Tourism Criteria for India (STCI) for accommodation, tour operators and beaches, backwaters, lakes and rivers sectors.

STCI was formulated by a committee constituted by the MoT was launched to develop tourism in India based on principles of sustainability and minimizing carbon footprints. While talking about sustainability, one should not only talk about the conservation of resources but also our culture and heritage. All the stakeholders in the tourism industry have been requested to be eco-sensitive and implement the STCI and have been requested to do business for long-term profits with diverse aims. The principles of sustainability that were incorporated were: Conservation of water, energy, culture, heritage, the revival of ancient architecture, involvement of communities, protection of wildlife and non-exploitation of women, children and weaker sections.

\section{D: GSTC (THE GLOBAL SUSTAINABLE TOURISM COUNCIL)}

With a global footprint and an experience, that would mean wonders for Indian Ecotourism, GSTC was a sure revelation for India. With a multitude of Ecotourism products and destinations, India needs a robust accreditation, assessment and certification system, that will create a better environment for the already existing Sustainable Ecotourism Model. With Forest Department across the country making an all-out effort to manage the forests through various conservation and preservation methods, GSTC would be a boon to the Ecotourism products spread across the country.

Karthik Davey a promoter of an Ecotourism Destination called Dholes Den (https://dholesden.com), near the Bandipur Tiger Reserve (BTR), simply mentioned, "the adoption of TOFTiger (www.toftiger.org) certification (approved by GSTC) is his biggest advantage." He added that "travellers with a bent of sustainability are coming as repeat guests to the resort." Dholes Den as a property is 95\% energy efficient with alternative energy-saving measures in place. Karthik says, "Sustainability is something that we believe should be a lifestyle not an act for a purpose." Dhole's Den through its biodigester generates bio-gas, which meets 5\% of the cooking fuel requirement (TOFTigers, 2014), which means a beginning has been done. Sustainable tourism promoters like Karthik will ensure a purposeful accreditation, assessment and certification framework which will do well for the tourism system in the long run.

During the research, which is a work in progress, we came across Mr Narasimha Bhatt (Destination promoter in the Kali Tiger Reserve (KTR) area in the northern part of the province of Karnataka), "believes in sustainable practices to ensure safety to visitors and the fact that he runs his business in an ecologically sensitive area, the aspects of waste disposal, keeping the area clean is important to conserve the environment. He goes on to say that the association (Kali Tourism association-KTA) acts unitedly and share best practices. But the issue is what suits one will not suit all, depending on the scale and number of rooms." Mr Bhatt considers himself to be a small entrepreneur who has the willingness to scale up on sustainability through various measures, but may not be in a position to get accreditation and certification. The researchers are of the view, those small entrepreneurs should be encouraged to come forward and take up accreditations and certifications such that they could be part of the juggernaut and encourage others to come forth.

Whilst researching for this paper, a discussion ensued, how would Community Based Ecotourism (CBE) products like, through the Special Purpose Vehicles (SPV); Ecotourism Management Committees (ETMC) in the province of Tamil Nadu and Eco-development Committees (EDC) in Karnataka, Maharashtra, Madhya Pradesh, Assam, Uttarakhand, Odisha, which are primarily run by the forest-fringe communities with active support from the State/Provincial Forest Departments be able to get to accreditation and certification. Speaking to the Presidents of the ETMCs and EDCs in Tamil Nadu, Karnataka and Maharashtra, the research team was able to establish that, in a good season the communities do earn income for themselves; part of the earning goes to the forest department, and a good amount goes towards employment and maintenance. The rest of the income is put as savings into a bank account jointly managed by the Forest Department and the Community. The income is used as "revolving loans" to anyone within the community who would like to put it to use through a payback mechanism managed by the community and the forest officers. In such a case, the representatives of the SPVs were clear, a mechanism should be drawn up to help CBE projects, which are practising Sustainable Ecotourism in the best of ways. This is food for thought, that we as a research team was able to identify, for there are a myriad of opportunities for GSTC to partner with the SPVs and ensure Ecotourism.

Talking to the Ranger of the Reception of the Mudumalai Tiger Reserve (MTR) in Tamil Nadu; Mr Vijay, who is in charge of the Theppakadu ETMC who suggests that for them the standards come from the top bosses of their department i.e., Tamil Nadu Forest Department (TNFD) and they have to adhere to the orders received and follow up. He believes in employing conscious environmental practices as the business of tourism for them happens in a Tiger Reserve. Here 


\title{
International Advanced Research Journal in Science, Engineering and Technology
}

Vol. 8, Issue 8, August 2021

\section{DOI: 10.17148/IARJSET.2021.8891}

too the research team is of the view, that GSTC along with TOFTigers and other organizations should bring about the education of the Forest Departments itself, such that they can be part and parcel of the accreditations team and even help in building frameworks for accreditation and certifications. This is one area, where one can see multiple opportunities for promoting quality Sustainable CBE.

What is that GSTC brings into the Ecotourism scenario of India? A robust system, that would not only be appreciated by the stakeholders but would help them to scale to better standards and evolve. By providing eco-labelling with the highest level of assurance, with third party certification at the highest level of assurance and the required standards, which would ensure the scrutiny of media, government, consumer watchdogs and others for it is based on a systematic, logical and transparent system (Durband, Randy, 2020).

\section{Levels of assurance}

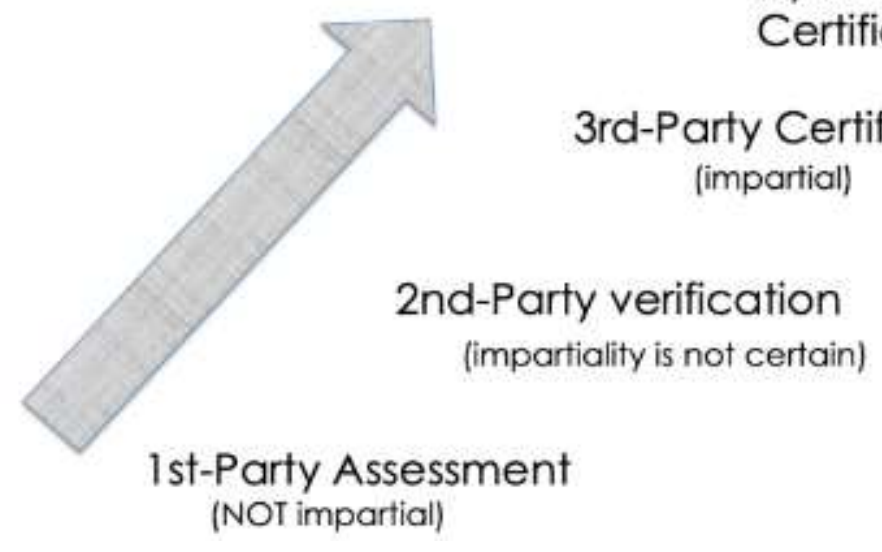

\author{
3rd-Party Certification \\ by an Accredited \\ Certification Body
}

Fig. 3: Levels of Assurance for Accreditation and Certification (Durband, Randy, 2020)

The levels of Assurance as can be seen from Fig (3) is a clear indication, that, a neutral third party assessing the sustainable practices of the provider provides much more credibility to an organization's claims. Without third-party certification, everything else is a self-assessment and is not a true certification, mentions, Mr Randy Durband the CEO of GSTC. The framework provided by Mr Durband of GSTC can be seen as evolved from what Honey Martha (2002) put forward in what can be considered as one of the earliest literatures on accreditation and certification: 'The Essential components of conformity assessment systems." A glance at the framework of 2002 will make us feel relevant to day and age.

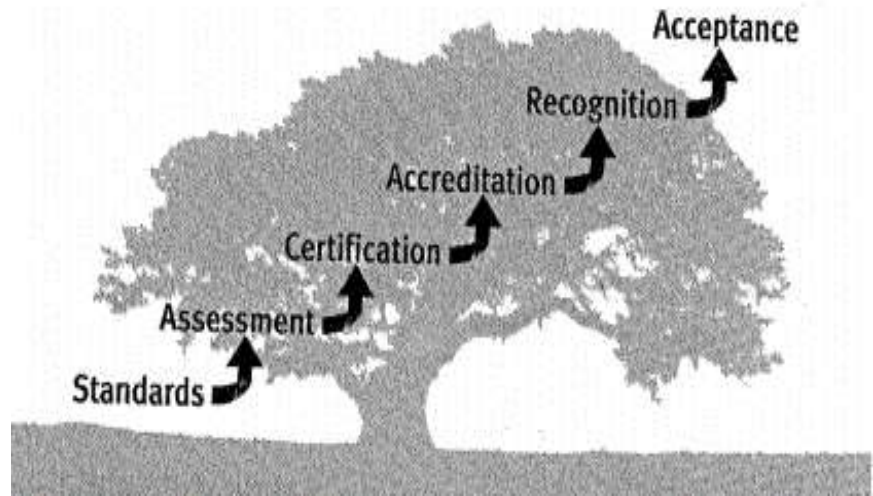

Fig 4: Essential components of conformity assessments (Honey, Martha, 2002)

GSTC provides an accreditation service that verifies that a Certification Body fulfils all the internationally recognized good practices for proper certification, here, in case, TOFTigers; The GSTC Accreditation Manual draws from standards for certification and accreditation from ISO and guidelines from the ISEAL Alliance, plus expert views from GSTC's global networks, and has compiled specialized guidance for credible certification for sustainable tourism. This creates the most competent and credible framework for certification, whereby the certifiers gain credibility from a hierarchy of oversight - accredited by GSTC, which strives to adhere to the Assurance Code of the ISEAL Alliance. 


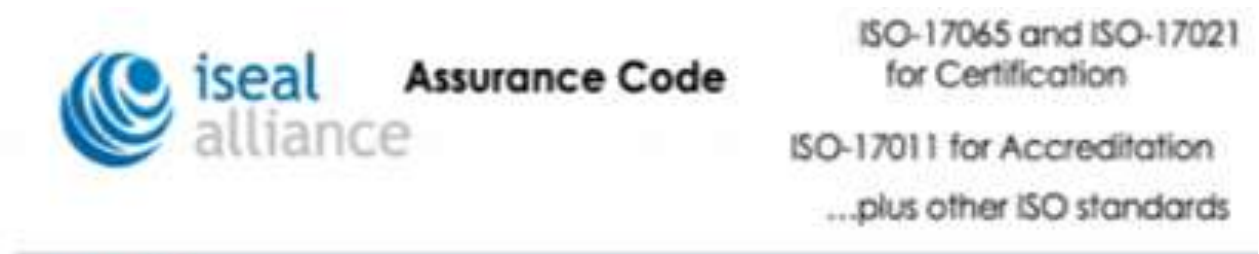

\section{Standard Owner (GSTC Criteria)}

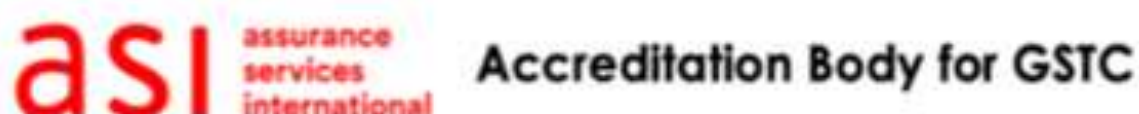

Fig 5: The GSTC accreditation players (Durband, Randy, 2020)

Fig (5) truly provides for an understanding of a compact and robust accreditation and certification mechanism that will be the most transparent of them all, and ensure quality towards eco-labelling measures in India, from a global perspective.

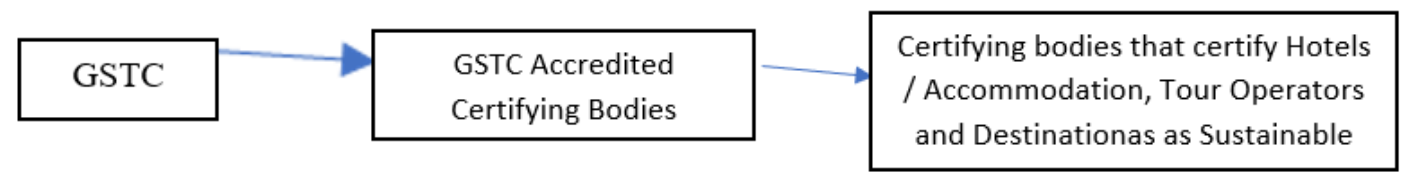

Fig 6: The GSTC accreditation and Certification continuum

Helping the reader, the academia and the practitioner to understand further the, "Accreditation Bodies undertake a process of approval that formally recognizes that a...certification program is competent to certify organizations to recognized standard. This procedure can be qualifying endorsing and licensing entities that perform certification of businesses, products, processes or services." (Black, R, 2015). From Fig (6) it is clear that GSTC accredits the Certifying Bodies (CB), who further Certify the Hotels, tour operators and Destinations.

Adding further to the frameworks of GSTC for accreditation and certification, as mentioned by Ramkumar CB, "Tourism cannot sustain unless it speaks the language of sustainability." (P Krishna Kumar, 2020), when he was discussing the Covid-19 pandemic and the way tourism practitioners sit back and think of the damage that has occurred through mass tourism. Thence, the clarion call for an important method of accreditation, certification, and even carrying capacity that needs to be focussed on. Another perspective was provided by Chirag, a Coffee Plantation farmer, in Sakleshpur located about 240 kilometres from Bangalore in the district of Hassan, who mentioned, "applying for membership of various organization which will help in accreditation and certification of the destination and/or the property, which assuage what the owner of the nature-based property can do further, rather than just practicing tourism, which will be killed, if one does so beyond capacity." Even if the tourism destination is an agricultural area, the owners would like to like to have sustainable accreditation which will help them to leverage further.

\section{CONCLUSION}

Tourism in general and Ecotourism, in particular, has evolved and grown leaps and bounds. Visitors across the globe besides, cultural tourism, prefer to travel to natural areas. As Karthik Davey of Dhole's Den, Bandipur Tiger Reserve (BTR) says, "visitors have gone green, there are many who prefer to travel to a destination, which is not only green but practices qualitative 'green tourism', what can be termed as sustainable tourism," Karthik, goes on to add, the visitors get interested in the Biogas plant that has been set up in the Ecotourism resort and are happy to follow norms of sustainability. Davey runs Dhole's Den, an Ecotourism resort that has been certified by TOFTigers who are approved by GSTC.

Thence, it can be seen that, with the advent of words such as green, environmentally friendly, sustainable and eco as powerful marketing slogans, it should come as no surprise that many organizations within the tourism industry have 


\title{
International Advanced Research Journal in Science, Engineering and Technology
}

\author{
Vol. 8, Issue 8, August 2021
}

\section{DOI: $10.17148 /$ IARJSET.2021.8891}

adopted these terms to attract customers. There are financially lucrative reasons for Ecotourism Destinations, hotels, restaurants, and vacation activities in this manner since surveys have indicated that travellers are willing to pay a premium for a product when they are aware that an organization is environmentally conscious and follows sustainability practices. When significant efforts are made to ensure practicing sustainable tourism and adopt measures that will help the environment (Airtransat, 2018); the visitors are happy to be part of such tourism products, and if the products are part of Ecotourism destinations, the visitors are willing to follow the tenets that have been put forward by the local stakeholders and the norms that are in place. As Mr Narasimha Bhatt who is one of the founders of the Kali Tourism Association in Joida Taluk of North Karnataka, which is part of the Kali Tiger Reserve (KTR) says, “...... sustainability means, be part of nature.....plastic is bad for nature..........so we advise the visitors to avoid plastic......and they follow...." This makes it even more clear that if the Ecotourism product has not been assessed, accredited and certified, as is the case with Bhatt, the visitors are willing to follow the norms and ensure.

There are many like Bhatt; who without Ecolabels have been doing wonderful work in sustainable tourism. The need would be getting such entrepreneurs into the rooster of GSTC approved mandates such that there will be an aspect quality that one can refer to and render as successful for the tourism system. The States/provinces of India and the Forest Departments (FD) are in the process of creating separate and specialized units called the Ecotourism Development Boards (EDB), which is headed by either an Elected Representative (a Minister or otherwise) and at times even Administrators/Bureaucrats who work along with various other Departments and units of the Governments, Industry appointees, Chambers of Commerce and Civil Society, with representation from the Non-Governmental Organizations (NGO). The EDBs can be another target to ensure traction towards, assessment, accreditation and certification because they can run some of the Ecotourism products with the support of the communities. Just to illustrate: the state of Tamil Nadu, runs ETMCs in 25 Ecotourism destinations with the support of the local community, which would mean, educating Departments would go a long to ensure, a proliferation of the thoughts of Ecotourism Certification measures.

Another opportunity that India provides is the fact that the Tourism Departments in the States and the Ministry of Tourism at the federal level play a dynamic role to ensure quality tourism in general and Ecotourism in particular. The State Tourism Departments (STD) too should be targeted to get to understand the procedures of assessments, accreditations and certification in their repertoire and Administrative Government Orders, which will usher in a mandate along with certain benefits that can be passed on to the Ecotourism products and destinations. Gujarat is one state in India, wherein the STD has in its policy document, brought about the need for assessment, accreditation and certification and is even as per the policy reverting the money spent on certifications. This is in a way a good start. Other states that could be immediately targeted would be Karnataka, Tamil Nadu, Kerala, Uttarakhand, Odisha, Maharashtra and even Assam. With the Federal Government Focussing on Atma Nirbhar Bharat a self-dependent India, and with Communities playing a role across the business and industry spectrum; and Ecotourism too being brought under the umbrella, it is pertinent that we work out a formula to ensure the objectives of an organization like GSTC.

\section{ACKNOWLEDGMENT}

First and foremost, the Madurai Kamaraj University, team of Prof. R. Kannan, Dr. S.Praveen Kumar, and Shaheed, Research Scholar and member of Dharthi NGO who were part of the research while collating the information. Late Prof. J.Balan, who was my initial Supervisor for the Research, who provided a birds eye-view to the study. Prof. (R) Soundararajan, who provided the initial inputs, which became pertinent as the study matured.

The Researchers would like to place on record that this research paper would not have been possible without the support of the Karnataka, Maharashtra, Madhya Pradesh and Tamil Nadu Forest Departments. Sincere thanks are to the support provided by: Mr Nitin Kakodkar IFS, Government of Maharashtra, Mr Praveen Gowda IFS, Field Director, TATR and Mr. Anirudh Chaoji, Biologist, TATR, Chandrapur and Ms. Pate Poonam Vilas IFS, Deputy Director, Navegaon-Nagzira Tiger Reserve, Sakoli. Mr KK Kaushal, IFS, APCCF and Field Director, Mudumalai Tiger Reserve, Ooty, Mr Raghunath IFS (R), Mr Basavaraj IFS (R), Tamil Nadu Forest Department and Mr Sanjay Srivastava IFS, Chennai. Appreciate the support and guidance given by Mr. Vinay Luthra IFS (R) and Dr Swaminath IFS (R) and Mr. Manoj Kumar IFS, for having been phenomenal mentors to the work on EDCs in Karnataka. Thanks also to Thiru. Dindigul Srinivas, former Forest Minister, Government of Tamil Nadu. Another person to thank is Thiru. Samad who helped us to get the initial permissions from the Tamil Nadu Government.

Having studied, practiced the various tenets of GSTC and also got an opportunity to interact, unlearn and learn, our special thanks to Ms. Ayako, Training Director, Training Aid (GSTC), Mr. Roi, General Manager, GSTC, Ms Antje Martins, GSTC STTP Trainer and the GSTC India team, Mr. CB Ram Kumar, Mr. Rajesh Nambiar and Ms. Aditi 


\title{
International Advanced Research Journal in Science, Engineering and Technology
}

\author{
Vol. 8, Issue 8, August 2021
}

DOI: $10.17148 /$ IARJSET.2021.8891

\section{REFERENCES}

[1]. Airtransat, "Sustainable Tourism - Transat's Hotel Partners in action," $3^{\text {rd }}$ May 2018, 4.46 minutes, https://www.youtube.com/watch?v=A4vHOE0kiEY\&t=286s (video accessed and retrieved on 20 $0^{\text {th }}$ July 2021)

[2]. ASQ, (2021). Learn About Quality, what are Environmental Management Systems (EMS)? American Society for Quality, https://asq.org/qualityresources/environmental-management-system accessed and retrieved on $12^{\text {th }}$ July 2021

[3]. Ali, Rafat (2018), The genesis of overtourism: Why we came up with the term and what's happened since, August $14^{\text {th }}, 2018$, https://skift.com/2018/08/14/the-genesis-of-overtourism-why-we-came-up-with-the-term-and-whats-happened-since/ accessed on $12^{\text {th }}$ May 2021. NOTE: Rafat Ali says, "We came up with 'overtourism' a simple portmanteau to appeal to people's baser instincts with an element of alarm and fear in it. That is the biggest reason why the term and its exploration by everyone has caught on...."It is said that the term overtourism was inadvertently coined on $14^{\text {th }}$ June 2016 in a normal communication between friends in a discussion and the word has caught on.

[4]. Akzonobel, (2016), AkzoNobel supporting the UN Sustainable Development Goals, https://report.akzonobel.com/2016/ar/casestudies/sustainable-development-goals.html accessed and retrieved on $31^{\text {st }}$ December 2019

[5]. Black, R., (2015), Accreditation, in Carl, Cater, B. Garrod, Tiffany, Low, The Encyclopedia of Sustainable Tourism, Wallingford, Oxfordshire Boston, CABI

[6]. Bricker, Kelly, "The International Ecotourism Society" (2017). Travel and Tourism Research Association: Advancing Tourism Research Globally. 11. https://scholarworks.umass.edu/ttra/2013marketing/White_Papers/11

[7]. Booking.com (2020), Booking.come reveals key findings from its 2020 sustainable travel report, https://news.booking.com/en-in/bookingcomreveals-key-findings-from-its-2020-sustainable-travel-report/ accessed and retrieved on $3^{\text {rd }}$ July 2021

[8]. Conserve Energy, (2021), What is Ecotourism, https://www.conserve-energy-future.com/principles-importance-benefits-ecotourism.php accessed and retrieved on $1^{\text {st }}$ July 2021

[9]. Constitution of India (2012a), Forest as an Entry was transferred from Entry 19 of the State List to the Concurrent List by the Constitution (Forty-second Amendment) Act, 1976, s. 57 (w.e.f. 3-1-1977), Lexis Nexis, Gurgaon, India.

[10]. Constitution of India (2012b), Forest as an Entry was transferred from Entry 20 of the State List to the Concurrent List by the Constitution (Forty-second Amendment) Act, 1976, s. 57 (w.e.f. 3-1-1977), Lexis Nexis, Gurgaon, India.

[11]. Day, Jonathon and Romanchek, Jennifer Lenore, "Sustainable Tourism for Destinations: Insights from the GSTC Destination Criteria 2.0 for Sustainable Tourism" (2020). Tourism Insights. Paper 1. http://dx.doi.org/10.5703/1288284317276

[12]. Durband, Randy, (2020), The Role of Standards to drive Sustainable Tourism, A Magazine for the Environmental Center for Arabs Towns, Dubai, Issue: 27, November 2020

[13]. ECO Tourism Australia, "Introduction to Ecotourism Australia and ECO Certification," $14^{\text {th }}$ April 2021, 6.53 minutes, https://www.youtube.com/watch?v=rvfvZ0IDWP4 (video accessed and retrieved on $19^{\text {th }}$ July 2021)

[14]. Eco Tourism Australia, (2021), Eco Certification, https://www.ecotourism.org.au/our-certification-programs/eco-certification/ accessed and retrieved on $19^{\text {th }}$ July 2021. NOTE: The link speaks about Eco Certification: i) Eligibility ii) How to apply iii) Benefits iv) Process v) Fee

[15]. Font, X., (2007), Ecotourism certification: Potential and challenges. In J. Higham (Ed.), Critical issues in ecotourism: Understanding a complex tourism phenomenon. Oxford, UK: Elsevier Ltd.

[16]. GKToday, (2014), Comprehensive Sustainable Tourism Criteria India (STCI) Launched, 27 ${ }^{\text {th }}$ August 2014, https://www.gktoday.in/currentaffairs/comprehensive-sustainable-tourism-criteria-india-stci-launched/ accessed and retrieved on $1^{\text {st }}$ June 2021

[17]. GSTC (2021), The Difference Between Ecotourism and Sustainable Tourism, https://www.gstcouncil.org/ecotourism/ accessed and retrieved on $19^{\text {th }}$ July 2021

[18]. GSTC (2021a), GSTC Destination Criteria, https://www.gstcouncil.org/gstc-criteria/gstc-destination-criteria/ accessed and retrieved on 18 July 2021. NOTE: These are GSTC Criteria v2.0, which are juxtaposed with the SDGs.

[19]. GSTC India Team (2021), Recommendations to the National Strategy and Roadmap for Sustainable Tourism in India by the Global Sustainable Tourism Council (GSTC) India Working Group. Freeda Maria Swarna, the Researcher of this paper has been recently co-opted as India Working Group and Member, Global Sustainable Tourism Council, initiated by the Rainforest Alliance, the United Nations Environment Programme (UNEP), the United Nations Foundation (UN Foundation), and the United Nations World Tourism Organization (UNWTO). (2021 onwards). https://www.gstcouncil.org/india/ working group: https://www/gstcouncil.org/about/people/gstc-working-groups/ The GSTC India Team which will focus on Sustainable Tourism opportunities and interventions and proliferate the global dialogue to the Eco-tourism scenario in India.

[20]. Galewska, Anula, "Mario Hardy on how PATA put sustainability at the Organization's core," Travindy Transforming Tourism News, 16 ${ }^{\text {th }}$ February 2017. https://www.travindy.com/2017/02/mario-hardy-pata-sustainability/ accessed and retrieved on $17^{\text {th }}$ July 2021

[21]. Honey, Martha, (2002), Ecotourism and Certification, Setting Standards in Practice, Island Press. ISBN: 1559639504

[22]. Honey, Martha, and Krantz, David, (2007), Global trends in coastal tourism, Center on Ecotourism and Sustainable Development (CESD), Marine program, World Wildlife Fund, Washington, DC. NOTE: Readers and Researchers can access the digital copy of the book at: https://www.responsibletravel.org/wp-content/uploads/sites/213/2021/03/global-trends-coastal-tourism-cesd-2008.pdf

[23]. McLaughlin, Juliene Melissa (2011), Ecotourism Assessment: Applying the Principles of Ecotourism to Paddle-Based Recreation in St. Lawrence Islands National Parks and Environs. A thesis submitted for Degree of Master of Environmental Studies to Queen's University, Kingston, Ontario, Canada. The thesis was accessed and retrieved on $2^{\text {nd }}$ July 2021 at: https://www.collectionscanada.gc.ca/obj/thesescanada/vol2/OKQ/TC-OKQ-6852.pdf

[24]. MP Forest, (2016), Madhya Pradesh Ecotourism Development Board, http://mpforest.gov.in/ecotourism/aboutus.html\#Profile accessed and retrieved on $19^{\text {th }}$ July 2021 .

[25]. NCCF, (2019), Network for Certification and Conservation of Forests, Concept note on Ecotourism Certification Standard in India. The document can be accessed at: https://www.nccf.in/wp-content/uploads/2019/10/concept-note-ecotourism.pdf

[26]. NCCF, (2019), About us, https://www.nccf.in/about-us/ accessed and retrieved on $19^{\text {th }}$ July 2021

[27]. P. Krishna Kumar, “95\% of tourism industry doesn’t understand sustainability: CB Ramkumar,”, ET Travel World, from The Economic Times, $22^{\text {nd }} \quad$ June 2021, https://travel.economictimes.indiatimes.com/news/tourism/experiential/95-of-tourism-industry-doesnt-understandsustainability-cb-ramkumar/83239243 accessed and retrieved on $1^{\text {st }}$ July 2021

[28]. P. Krishna Kumar, "Tourism should learn to speak the language of sustainability: CB Ramkumar," ET Travel World, from The Economic Times, $22^{\text {nd }}$ April 2020, https://travel.economictimes.indiatimes.com/news/tourism/experiential/tourism-should-learn-to-speak-the-language-ofsustainability-cb-ramkumar/75292042 accessed and retrieved on $2^{\text {nd }}$ July 2021

[29]. Pande, Neha and Sharma, AK., (2018), Why Uttarkhand's Ecotourism Development is Being Mismanaged, Economic and Political Weekly (EPW), Vol.53, Issue No. 49, 15 December 2018. https://www.epw.in/engage/article/uttarakhand-ecotourism-development-being-mismanaged accessed and retrieved on $20^{\text {th }}$ July 2021

[30]. PATA, (2021), About PATA, https://www.pata.org/about-pata accessed and retrieved on $16^{\text {th }}$ July 2021 


\section{DOI: $10.17148 /$ IARJSET.2021.8891}

[31]. Patterson, C., (2001), The Business of Ecotourism: The Complete Guide for Nature and Culture-Based Tourism Operators, Explorer's Guide Publishing Second Edition ISBN: 9781879432444

[32]. Peeling, Caitlin, (2021), Ten Principles to identify a trustworthy sustainability system, Iseal, https://www.isealalliance.org/sustainabilitynews/ten-principles-identify-trustworthy-sustainability-system accessed and retrieved on $19^{\text {th }}$ July 2021: NOTE: ISEAL, based in London, UK, works to improve the impacts of members and the partners by i) defining credible practice based on emerging global consensus, ii) convening forums for collaboration, sharing of experience, and collective action, iii) delivering expertise, advice and training, iv) facilitating and promoting innovation to strengthen sustainability systems.

[33]. Rainforest Alliance (2002), Sustainable Tourism Stewardship Council: Raising the Standards and Benefits for Sustainable Tourism and Ecotourism Certification, final report to the Ford Foundation, December 2002, version 8.4. available at: http://www.rainforestalliance.org/tourism.cfm?id=council

[34]. TIES, (2019), What is Ecotourism, https://ecotourism.org accessed and retrieved on $1^{\text {st }}$ July 2021

[35]. TOFTigers (2014), Sustaining the Wild, Responsible steps towards best practice. TOFTigers handbook for accommodation providers in and around Natural Habitats. (Third Edition, 2014). For more information, http://www.toftigers.org/Resources/Default.aspx

[36]. UN SDG, https://sdgs.un.org/goals accessed and retrieved on $19^{\text {th }}$ July 2021

[37]. UNEP, (2002), Quebec Declaration on Ecotourism defines basis for its international development, https://www.un.org/press/en/2002/unep113.doc.htm accessed and retrieved on 30 ${ }^{\text {th }}$ June 2021

[38]. World Ecotourism Summit (2002), Final Report of the Conference of Quebec, 19 - 22 May 2002. Published by the World Tourism Organization (WTO) and the United Nations Environment Program (UNEP), Madrid, Spain. ISBN: 9284405505

\section{BIOGRAPHY}

\section{Author 1: Freeda Maria Swarna M}

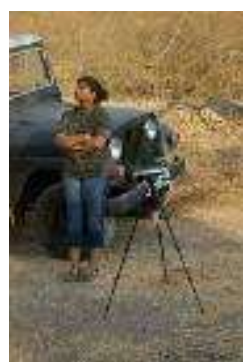

Over 15 years of experience in the Sustainability, Conservation Science, Environment, Communities and Tourism domains. My strength lies in combining Applied Sciences and the integration of sound research with robust implementation. Through Dharthi (NGO), our suggestions have been included in Government dossiers and reports for better management of tourism and communities for sustained livelihoods, and contributed towards policy decisions in the Ecotourism sector, that is inclusive and sustainable. Extensive field knowledge (Pan India) and thorough understanding of the government's laws and rules including the schemes and programmes in my field of work is my strength. Strategic Planning, programme management, stakeholder collaborations, community engagements, impact investing, Social, Environment and Tourism Impact Assessments are my interests. Through the works with the Forest Departments of Karnataka, Tamil Nadu, Maharashtra and Madhya Pradesh, our presence remains. Dharthi, was nominated to the Karnataka Ecotourism Development Board as member of the General Body, during the three-year tenure, I was instrumental in conducting Cumulative Impact assessment (CIA) studies, have consultations with stakeholders for a robust Ecotourism Policy for the State. Freeda is in the process of authoring two books, one on Ecotourism, and have published articles and papers to my credit. My penchant for writing, I have put up a blogsite called https://highwaymybeckoning.com, that will have impactful stories of my travels, people and places. Freeda is a Doctoral Research Scholar at CTHM, Madurai Kamaraj University, Madurai in the domain area of Tourism Management.

\section{Author 2: Shaheed Khan}

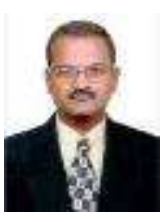

Academically qualified in the areas of and armed with Post Graduate Degrees in History, Tourism, Business Administration and Law; Shaheeds' focus area has been Tourism, Services, Mergers and Acquisitions and Human Resources. He also has a Micro-specialization in Strategy Management from Indian Institute of Management Kozhikode and a Corporate Program in Leadership Management from Harvard School of Publishing. He brings to the table multiple facets of functioning that supports in any area of academics and practice in the corporate world. Having worked in the Government, Private and Social Sectors, Shaheed has got to broad understanding of Tourism, Travel and Hospitality (TTH). Besides being a Doctoral Research Scholar in Tourism Management at CTHM, Madurai Kamaraj University, Madurai, Shaheed is the Director for Training and Research with Dharthi NGO, Bangalore. He is also an Adjunct Faculty for a Leading Deemed to be University, and engages Class session for Corporates in Leading IT and manufacturing Companies of India.

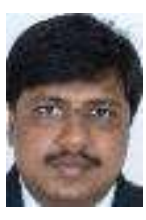

\section{Author 3: R. Kannan}

With more than three decades of teaching and two decades of Research experience, Dr. R. Kannan, is the Professor and Director of the Centre for Tourism and Hotel Management (CTHM), Madurai Kamaraj University, Madurai. Besides PhD in Tourism Management, Prof. Kannan has three Post Graduate Degrees and Diploma in French and Teacher Training in Hotel Management. He has been the Supervisor for 13 Researchers, and 9 are in the to be submitted in due course. He has close to 100 research publications to his credit and presented pa Research papers in a multitude of Seminars and Conferences. 
International Advanced Research Journal in Science, Engineering and Technology

Vol. 8, Issue 8, August 2021

DOI: $10.17148 /$ IARJSET.2021.8891

\section{Author 4: S. Praveen Kumar}

With a decade of teaching and research experience, besides nine years in the tourism industry, Dr. Praveen has successfully supervised six PhD students and is guiding thee at present. His specialization areas of Services Marketing, Tourism Management and Entrepreneurship helps him to engage with the various aspects of Tourism and Travel Management and bring the best out for the business of Travel. His research abilities have ensured that the best reaches out to the academia and the practitioner. His research papers been selected for best research papers many a time. 